\title{
CaUdAL ANAESTHESIA IN PAEDIATRIC PATIENTS
}

\author{
M.G. Soliman, S. ANSARA, ANd R. Laberge
}

THE USE of regional anaesthesia in paediatric patients is limited in most medical centres, mainly due to lack of patient co-operation and different anatomical landmarks. Though its use is limited, caudal block may be a useful tool in paediatric anaesthesia for certain procedures.

Caudal anaesthesia may be used as the sole anaesthetic technique when general anaesthesia represent a risk, or it may be used in association with light general anaesthesia to decrease intraoperative reflexes and, above all, to relieve post-operative pain.

Some published articles ${ }^{1-7}$ have indicated the usefulness of caudal anaesthesia for the purposes mentioned, but details of the techniques used were hardly mentioned. In this report we intend to describe in detail our technique for caudal anaesthesia in children and our experience with it.

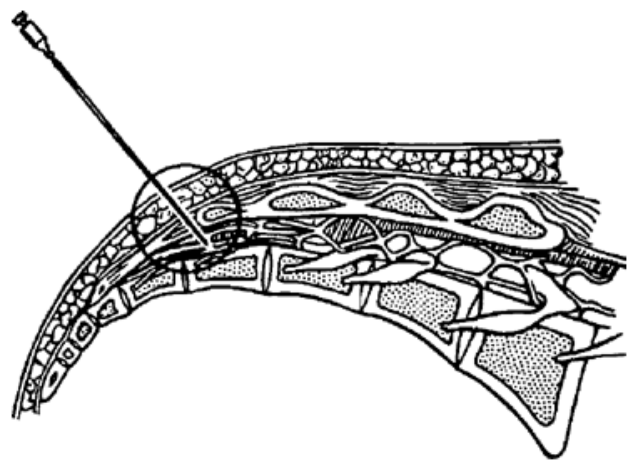

Figure 1. Anatomy of the sacral canal in the infant and initial position of the needle for caudal block through the sacral hiatus.

lower end of the sacrum. It has a bony process on each side, the "sacral cornu", representing the inferior articular process of the fifth vertebra. The hiatus is covered by the sacrococcygeal ligament. At birth, the sacrum is similar to that of adults the five sacral vertebrae, but differs in being partially ossified. The ossification centres of the vertebral bodies appear between the 10th and 20 th weeks of gestation, while those of the vertebral arches appear between the 24th week and the 32nd week. The vertebral arches become completely ossified and unite together and with the vertebral bodies by the age of eight years. The sacral canal is triangular in transverse section. It contains the sacral nerves, blood vessels, lymphatics, and areolar tissue. It also contains the dural and arachnoid sacs, which usually terminate at the level of the second sacral vertebra; however, sometimes they may extend to the third or fourth sacral vertebrae.

The sacral hiatus is formed by failure of fusion of the fifth sacral vertebral arch. It can be easily palpated in children as a triangular space at the

M.G. Soliman, M.D., Assistant Professor; S. Ansara, M.D., Assistant Professor; and R. Laberge, M.D., Assistant Professor. Department of Anaesthesia, University of Montreal. Hôpital Sainte-Justine Pour Les Enfants, 3175 Côte Ste-Catherine, Montréal, Qué., H3T IC5.

Reprint requests to: Dr. M.G. Soliman.

Canad. Anaesth. Soc. J., vol. 25, no. 3, May 1978

\section{Technique}

The sacral canal in children can be reached through the sacral hiatus or by the trans-sacral route.

(A) through the sacral hiatus

This is the commonest route.

Positions; One of three positions may be used. These are (a) the prone position with partially flexed hips and knees, (b) the knee chest position. and (c) the lateral position with maximum flexion of both hips and knees.

We found that the lateral position is the most practical, since it is easy to manipulate anaesthetized paediatric patients in that position.

Procedure: After identification of the sacral hiatus, the skin is prepared with alcohol-iodine needle attached to a syringe containing the local anaesthetic solution. The needle is introduced in the mid-line at an angle of $70^{\circ}-80^{\circ}$ to the coronal plane and perpendicular to other planes (Figure 1). Once the sacrococcygeal ligament is pierced, as indicated by loss of resistance, the angle of the solution and pierced with a 23-gauge 3/4-inch 


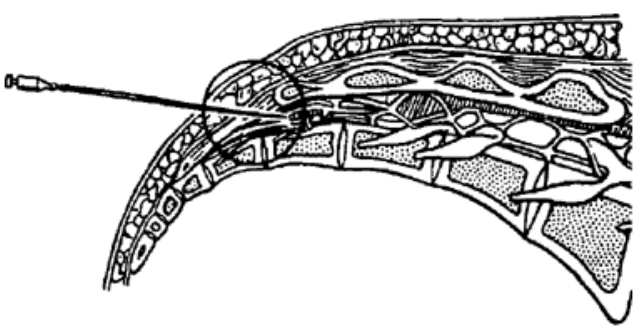

FIgure 2. Position of the needle after piercing the sacrococcygeal membrane for caudal block through the sacral hialus.

needle is changed to $20^{\circ}$ to the coronal plane and advanced about half a centimeter (Figure 2). If aspiration is negative for blood and cerebrospinal fiuid, we inject the local anaesthetic, watching for subcutaneous infiltration. The injection should be easy and free of resistance.

(B) Transsacral route; (Figure 3)

The trans-sacral route can be used in children under eight years of age, due to the lack of ossification of the vertebral arches.

The technique is exactly the same as the transhiatal route except that the needle is advanced in the mid-line vertical to the skin in all planes, at the level of the fourth sacral vertebra. The needle is advanced until the tip traverses the unossified vertebral arch, as indicated by loss of resistance. The local anaesthetic is injected after negative aspiration. We feel that this route should be used only in cases in which it is difficult to identify the sacral hiatus. If this route is used it is advisable to introduce the needle as low as possible to avoid dural or arachnoid puncture.

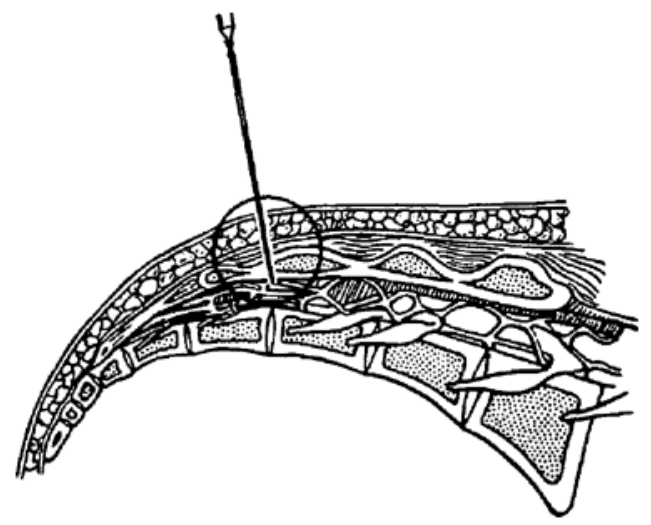

Figure 3. Position of the needle for caudal block by the trans-sacral route in children.
Volume and concentration of the anaesthetic agents

The dose required for a successful caudal block is difficult to determine, since this depends on the capacity of the sacral peridural space, which in turn varies with the height, weight and age.

Several formulas have been described in the literature, using one of these variables as a guide to the dose required.

Spiegel ${ }^{2}$ used the height as a guide to the dose required. His formula to obtain a level above $D_{10}$ was $\mathrm{V}=4+(\mathrm{D}-15) / 2$, where $\mathrm{V}=$ the volume in $\mathrm{ml}$ and $\mathrm{D}$ is the distance between $\mathrm{C}_{7}$ and the sacral hiatus in $\mathrm{cm}$.

Using the weight as a guide, Davenport ${ }^{10}$ recommended a dose of $5 \mathrm{mg}$ lidocaine $/ \mathrm{kg}$. He used lidocaine one per cent with epinephrine for children under five years of age and lidocaine $1.5 \mathrm{per}$ cent with epinephrine for children over five years.

Others $^{3}$ recommended lidocaine $6-8 \mathrm{mg} / \mathrm{kg}$ using 1.5 per cent for children two to six years of age and two per cent for six to thirteen years.

With these dosages it is difficult to predict the level of the blocks. Schuite-Steinberg, et al. studied the spread of different local anaesthetics after caudal anaesthesia in children and correlated the dose required per segment to the age, weight, and height. ${ }^{11.12}$ They found that there is a correlation between these factors and the dose. The highest correlation coefficient is between the dose per segment and the age $(r=0.95)$.

The regression equation obtained when they used lidocaine one per cent with epinephrine was $y=0.0558+0.09729 \times$ age (years) $y$ is the dose in $\mathrm{ml} /$ segment.

They also found a parallel relation with other local anaesthetics.

Using this formula we found that lidocaine one per cent in a dose of $1 \mathrm{ml} /$ year of age will give a block level within the lumbar region in most cases.

Other agents such as bupivacaine 0.25 per cent will give nearly the same level as lidocaine one per cent if the same volume is used. Using lidocaine in other concentrations necessitates volume adjustment so that the total dose in $\mathrm{mg}$ should be the same.

\section{METHOD}

We used caudal block in 120 patients to relieve the post-operative pain after circumcision or correction of hypospadias. Table I shows some features of these patients. Their age ranged from 
TABLE I

Some Detalls of 120 Paediatric Patients Who Had Caudal Blocks

\begin{tabular}{|c|c|c|c|c|c|c|c|c|c|}
\hline \multirow[b]{2}{*}{ No. } & \multicolumn{4}{|c|}{ Age (years) } & \multirow{2}{*}{$\begin{array}{c}\text { Weight } \\
\text { kg }\end{array}$} & \multicolumn{2}{|c|}{ ASA } & \multicolumn{2}{|c|}{ Hospitalization } \\
\hline & $<1$ & $1-5$ & $5-10$ & $>10$ & & I & II & Yes & No \\
\hline 120 & 15 & 66 & 53 & 6 & $6.6-51$ & 118 & 2 & 10 & 110 \\
\hline
\end{tabular}

TABLE II

Summary of the ANaEsthetic Technique

\begin{tabular}{|c|c|c|c|c|c|c|}
\hline \multicolumn{2}{|c|}{ Premedication } & \multicolumn{2}{|c|}{ Induction } & Maintenance & \multirow[b]{2}{*}{ Surgery time } & \multirow[b]{2}{*}{ Breathing } \\
\hline Yes & No & Inhalation & i.v. & $\mathrm{N}_{2} \mathrm{O}_{2}:$ Halothane & & \\
\hline 104 & 16 & 56 & 64 & $70: 30:$ & $35-95 \mathrm{~min}$ & Spontaneous \\
\hline
\end{tabular}

four months to 18 years, weight varied from 6.6 to $51 \mathrm{~kg}$. Two patients were ASA status II the rest were ASA status I. The large majority were outpatients.

Table II shows a summary of the anaesthetic technique used. Pre-anaesthetic medication in form of meperedine [ $\mathrm{mg} / \mathrm{kg}$, hydroxyzine $\mathrm{HCl}$ ] $\mathrm{mg} / \mathrm{kg}$ and atropine or scopolamine $0.01 \mathrm{mg} / \mathrm{kg}$ were given intramuscularly one hour before induction to 104 patients. The others received no premedication. Inhalation induction with halothane, nitrous oxide and oxygen was used in 54 patients.

Other patients were induced with thiopentone $5 \mathrm{mg} / \mathrm{kg}$ intravenously. Anaesthesia was maintained with nitrous oxide-oxygen $\left(\mathrm{FI}_{\mathrm{O}_{2}} 0.3\right)$ and halothane. When the patients stabilized after induction, caudal anaesthesia was done in the lateral position. The volume used was $1 \mathrm{ml} /$ year of age of either lidocaine one per cent or bupivaine 0.25 per cent plain.

Lidocaine was used in 28 patients, lidocaine with epinephrine in 38 patients, and bupivacaine in the rest of the group. Once caudal anaesthesia is done, the halothane concentration is decreased to 0.5 per cent just to keep the patient asleep.

During the operation the heart rate and rhythm were observed, arterial blood pressure was mea- sured and an open vein was maintained with infusion of five per cent dextrose in 0.2 per cent saline. The block was judged satisfactory when there was no response to the surgical stimulus, no reflex laryngospasm, quiet recovery and no analgesics required in the post-operative period. One to two months after the operation the parents were contacted and questioned about possible complications.

\section{RESULTS}

The mean doses/kg required for satisfactory caudal block in our study are shown in Table III.

TABLE III

The Mean Dose Required in $\mathrm{MG} / \mathrm{KG} \pm \mathrm{S} . \mathrm{E}$.

\begin{tabular}{ll}
\hline \hline Lidocaine & Bupivacaine \\
\hline $3.2 \pm 0.1$ & $0.72 \pm 0.02$ \\
\hline
\end{tabular}

The mean doses were well below the toxic doses and those recommended on the basis of weight.

The block was satisfactory in $\mathbf{9 7 . 5}$ per cent of the patients (Table IV). In three patients the block was judged a failure. These patients re-

TABLE IV

COMParison of Satisfactory and Non-Satisfactory Block

\begin{tabular}{lcccc}
\hline & \multicolumn{3}{c}{ Recovery room time } \\
& No. & in min & 1st dose of narcotics & Reaction \\
\hline Satisfactory & 117 & $25-45$ & $>6 \mathrm{~h}$ & Quiet \\
Not satisfactory & 3 & $60-90$ & $<15$ min & Agitated \\
\hline
\end{tabular}


quired halothane concentration more than one per cent to block the response to surgical stimulation and their post-operative course was similar to that of patients who had no block. They were agitated and required narcotics in the first $15 \mathrm{~min}$ utes post-operatively.

Patients with satisfactory block remained in the recovery room for a period of 25 to $45 \mathrm{~min}$ utes. They required no analgesics for at least six hours, which is the minimum stay for outpatients.

During operation we noticed no change in heart rate and rhythm. Arterial blood pressure was stable and other vital signs were normal.

In six hospitalized patients no analgesics were given during the first 24 hours after operation. We have not observed a difference between lidocaine and bupivacaine when used for the block.

The parents were satisfied with the post operative course of their children. There were no surgical or anaesthetic complications during the first 4 to 10 weeks post-operatively.

\section{Discussion}

Some perineal and genital surgical procedures are followed by moderate to severe postoperative pain. Examples of these are circumcision and correction of hypospadias. Feeling the pain after these procedures may cause the child to manipulate the operative site. This may lead to post-operative bleeding, infection, or other surgical complications. Thus post-operative relief of pain may play an important role in decreasing the incidence of post-operative surgical complications.

We have found that caudal anaesthesia is an easy and satisfactory method for complete relief of post-operative pain. The block leads to a quiet comfortable recovery with a shorter period in the recovery room. There were no side effects from the block, which makes caudal anaesthesia superior to narcotics especially in out-patients. There were no anaesthetic or surgical complications in these patients.

Some anaesthetists prefer not to do caudal anaesthesia before the child can walk, fearing that if there is a delay in walking the anaesthetist could be blamed for it. We feel that our aim is to relieve post-operative pain with minimal side effects regardless of the patient's age. If neurological complications happen, they have no age preference. We took the precaution to have all our patients seen by a paediatrician and only normal children were given caudal anaesthesia. We do not use caudal anaesthesia in the presence of neurological or metabolic diseases. A control visit to the paediatrician post-operatively will help to determine post-caudal neurological complications if these are present.

The possibility of neurological complications ${ }^{13}$ and medicolegal consequences may be the major factors in limiting the use of caudal anaesthesia. Although the exact aetiology of these complications is not known, the use of a good technique with particular attention to sterility may be a major factor in reducing or eliminating them.

\section{SUMmaRY}

We have described our technique of caudal anaesthesia in children. This technique was used for relief of post-operative pain in 120 patients. Relief of pain was complete. Post-operative recovery was quiet and comfortable, with no side effects. The surgeons, the parents and recovery room personnel were satisfied. There were no surgical or anaesthetic complications.

\section{RÉSUMÉ}

Ce travail tend à démontrer l'utilité de l'anesthésie caudale chez l'enfant subissant une intervention chirurgicale périnéale douloureuse.

Une technique utilisée chez 120 patients, est décrite après un bref rappel anatomique.

Les patients (chirurgie externe en grande majorité) subissaient une chirurgie pour circoncision ou réparation d'hypospade: l'âge varie de 4 mois à 18 ans, le poids de 6.6 à $51 \mathrm{~kg}$.

118 patients étaient ASA status I.

2 patients étaient ASA status II.

104 patients ont reçu une prémédication, une heure avant l'induction.

16 patients n'ont pas été prémédiqués.

L'induction de l'anesthésie était faite par inhalation (54 pts) ou à l'aide d'un barbiturique endoveineuse.

Après stabilisation de l'anesthésie, le patient était placé en décubitus latéral et on procédait à la caudale à l'aide de lidocaine 1 pour cent sans épinephrine ( $28 \mathrm{pts}$ ) avec épinephrine ( $38 \mathrm{pts}$ ) ou bupivaine 0.25 pour cent ( $54 \mathrm{pts})$ à raison de 1 $\mathrm{ml} /$ année d'âge.

L'anesthésie générale était dès lors maintenue avec l'halothane 0.5 pour cent pour maintenir le patient stable et immobile.

La moyenne des doses utilisées se situe bien en deça de la dose toxique (Table III). 
Cette technique fut efficace dans 97.5 pour cent des cas qui ne nécessitèrent aucune analgésie pour un minimum de six heures post-opératoire.

L'anesthésie caudale est une technique facile d'exécution chez l'enfant et l'analgésie est très satisfaisante pendant l'operation et dans la periode post-opératoire.

La possibilité de complications neurologiques et de problèmes médico-légaux sont probablement les objections qui font que cette technique régionale est d'usage limité.

Une attention particulière à la stérilité et à la technique de bloc est primordiale pour diminuer ou même éliminer cette éventualité.

Dans notre étude de 120 patients nous n'avons aucune complication de cet ordre.

\section{REFERENCES}

1. Touloukian, R.J., Wugmeister, M., Pickett, I.K., \& Herre, F.W. Caudal anesthesia for neonatal anoperineal and rectal operations. Anesth. Anal, 50: 565 (1971).

2. SPIECEL, P. CaUdal ane sthesia in pediatric surgery. Anesth. Anal. 41:218 (1962).

3. Melman, E., Penuelas, J., \& Narrufo, J. Reg- ional anesthesia in children. Anesth. Analg. $54: 387$ (1973).

4. KAY, B. Caudal block for post-operative pain relief in children. Anaesthesia 29:610(1974).

5. Lowrey, C.J. \& Macdonald, I.H. Caudal aneşthesia in infants and children. Anesthesia and Intensive Care 1: 547 (1973).

6. Shakeela, Z.H. Caudal anesthesia in infants. Anesth. Analg. 56: 686 (1977).

7. Ruston, F.G. Epidural anesthesia in pediatric patients. Anesth. Analg. 36: 76 (1957).

8. DAvis, D.V. Gray's anatomy descriptive and applied, 34th ed. p. 281, Longmans, London, England.

9. AREY, L.B. Developmental anatomy: a textbook and laboratory manual of embryology, revised, 7th ed., Saunders, Philadelphia.

10. Davenport, $H$. Pediatric anesthesia, 2nd ed. p. 143, Year-book Medical Publisher, Chicago (1973).

II. Schulte-Stienberg, O. \& Rahlfs, V.W. Caudal ane sthesia in children and spread of $1 \%$ lidocaine. Brit. J. Anaesth. 42: 1093 (1970).

12. Schulte-Stienberg, O.\& Rahlfs, V.W. Spread of extradural analgesia following caudal ingestion in children; a statistical study. Brit. J. Anaesth. 49: 1027 (1977).

13. Massey-Dawkins, C.J. An analysis of the complications of extradural and caudal block. Anaesthesia $24: 554$ (1969). 